El Bılall, H., Bassole, I. H. N., Dambo, L., Berjan, S. (2020): Climate change and food security. Agriculture and Forestry, 66 (3): 197-210.

DOI: 10.17707/AgricultForest.66.3.16

\title{
Hamid EL BILALI ${ }^{1}$, Imaël Henri Nestor BASSOLE ${ }^{2}$, Lawali DAMBO ${ }^{3}$, Sinisa BERJAN ${ }^{4}$
}

\section{CLIMATE CHANGE AND FOOD SECURITY}

\section{SUMMARY}

Climate change is one of the most pressing challenges facing humanity in the Anthropocene era. It is widely admitted that climate change will have farreaching impacts including on food security. Therefore, this review paper analyses the multifaceted relations between climate change and food security. In particular, the paper explores the impacts of climate change on the four dimensions of food security (i.e. food availability, food access, food utilization, stability). It draws upon a review of scholarly literature indexed in the Web of Science. The analysis of the literature shows that there is a dual relationship between climate change and food security; on the one hand, climate change affects all the dimensions of food security and, on the other hand, the quest for food security has implications in terms of climate change. As for food availability and supply, climate change is widely believed to reduce crop yields and livestock productivity especially in the countries of the Global South. Effects on food production and availability as well as the impacts of extreme climate events affect both food physical and economic accessibility. The changes in production systems induced by climate change may induce changes in dietary patterns and food utilization. Climate change will also affect the stability and resilience of food systems with consequences in terms of long-term food security. Moreover, the quest for food security, through agricultural intensification and agricultural land expansion, increases greenhouse gas emissions from deforestation and land use changes. The intricate relation between climate change and food security makes the case for integrated policies that maximise co-benefits while addressing trade-offs. That is fundamental to make sure that 'climate action' will not jeopardize the achievement of 'zero hunger' and vice-versa.

Keywords: Climate change, food security, food availability, food access, food utilisation, food system, agriculture.

\footnotetext{
${ }^{1}$ Hamid El Bilali, (corresponding author: elbilali@iamb.it), International Centre for Advanced Mediterranean Agronomic Studies (CIHEAM-Bari), Valenzano (Bari), ITALY.

${ }^{2}$ Imaël Henri Nestor Bassole, Joseph KI Zerbo University of Ouagadougou, Ouagadougou, BURKINA FASO.

${ }^{3}$ Lawali Dambo, Abdou Moumouni University of Niamey, Niamey, NIGER.

${ }^{4}$ Sinisa Berjan, Faculty of Agriculture, University of East Sarajevo, East Sarajevo, BOSNIA AND HERZEGOVINA.

Notes: The authors declare that they have no conflicts of interest. Authorship Form signed online. 


\section{INTRODUCTION}

According to the Food and Agriculture Organisation of the United Nations (FAO, 2009), "Food security exists when all people, at all times, have physical, social and economic access to sufficient, safe and nutritious food to meet their dietary needs and food preferences for an active and healthy life". Food security is built on four pillars (Committee on World Food Security, 2012; Ericksen, 2008; FAO et al., 2013; United Nations System High Level Task Force on Global Food Security, 2011): food availability (i.e. sufficient quantities of food produced and supplied on a consistent basis); food access (i.e. physical access and affordability); food utilisation (i.e. proper use of food based on basic nutrition knowledge); and stability in food availability, access and utilization. The concept of food security (FS) has been central in the discussion on sustainable development. Indeed, the first Millennium Development Goal (MDG) aimed to "Eradicate extreme poverty and hunger" (United Nations, 2015a). More recently, from 2016 on, the second Sustainable Development Goal (SDG) "Zero Hunger" aims to "End hunger, achieve food security and improved nutrition and promote sustainable agriculture" (United Nations, 2015b). However, despite efforts made over the last decades, food insecurity is still a pressing issue in many countries, especially developing ones. In fact, the report on the State of Food Security and Nutrition in the World 2019 (FAO et al., 2019) shows that more than 820 million people were hungry in 2018, especially in Africa, Latin America and Asia. Nevertheless, it was estimated that over 2 billion people do not have a good FS status, including $8 \%$ of the population of developed countries (e.g. North America and Europe), when also considering people affected by moderate levels of food insecurity (FAO et al., 2019).

Food insecurity is a symptom of the dysfunction of the global food system (Capone et al., 2016; Capone et al., 2018; El Bilali et al., 2018; El Bilali, 2018; El Bilali, 2019), which is under the unprecedented confluence of various pressures (FAO, 2014) such as climate change (FAO, 2016). Indeed, FAO (2016) puts that "Through its impacts on agriculture, climate change will have negative effects on food security in all of its dimensions [...] While food security will be affected through other channels - for example, by extreme weather events that reduce urban dwellers' incomes and thus access to food - agriculture is a key channel through which climate change affects food security" (p. 8). Climate change affects the natural resources (e.g. water, land) used in agricultural production (Cadro et al., 2019; Čustović et al. 2012; Simunic et al., 2019). Beyond its impacts on agriculture and food security, climate change (CC) is one of the most pressing challenges facing humanity (Intergovernmental Panel on Climate Change, 2012; Steffen et al., 2015; United Nations, 2015b). It is central in the ongoing debate on sustainable development. Indeed, the SDG 13 "Climate action" aims to "Take urgent action to combat climate change and its impacts" (United Nations, 2015b). Furthermore, CC represents a threat towards the achievement of different SDGs such as SDG2 "Zero hunger" (Mugambiwa \& Tirivangasi, 2017). In this context, the present paper aims to analyse the 
multifaceted relations between $\mathrm{CC}$ and food security. In particular, it explores the impacts of $\mathrm{CC}$ on the four dimensions of food security. The paper draws upon a review of all documents indexed in the Web of Science viz. Science Citation Index Expanded (SCIE), Social Sciences Citation Index (SSCI), Arts \& Humanities Citation Index (A\&HCI), Conference Proceedings Citation Index Science (CPCI), and Emerging Sources Citation Index (ESCI). A search was performed in June 2020 using the Title-Abs-Key search query \{climate change\} AND \{food security .

\section{EFFECTS OF CLIMATE CHANGE ON FOOD SECURITY DIMENSIONS Climate change and food availability}

Climate change affects food availability through its adverse impacts on crop yields, and fish and livestock productivity, especially in Sub-Saharan Africa (SSA) and South Asia, where most of the food insecure people live. Indeed, Zougmoré et al. (2018) suggest that "[...] without appropriate interventions, climate change and variability will affect agricultural yields, food security and add to the presently unacceptable levels of poverty in sub-Saharan Africa". The effects of $\mathrm{CC}$ will be particularly severe in regions where agriculture is predominantly rain-fed such as in SSA, which makes it highly vulnerable to climate fluctuations and droughts (Adhikari et al., 2015; Cooper et al., 2008; Muchuru \& Nhamo, 2019). Webersik and Wilson (2009) put that "African economies are closely linked to natural resources and rely heavily on agriculture, largely rain fed [...]. It is predicted that Africa will be particularly vulnerable to climate change and climate variability associated with biodiversity loss, food insecurity, water scarcity and an increase in drought frequency" (p. 400). CC will reduce the yields and productions of the main staple crops such as rice (Akinbile et al., 2015; van Oort \& Zwart, 2018), wheat (Trnka et al., 2019) and maize (Davenport et al., 2018; Freduah et al., 2019; Murray-Tortarolo et al., 2018; Waha et al., 2013), CC is also predicted to affect livestock productivity (Godber \& Wall, 2014; Mare et al., 2018; Naah \& Braun, 2019). Ramasamy (2010) put that "Rising temperatures, more intense droughts, floods, and greater weather variability all mean productivity losses to crops and livestock" (p. 185). Some studies also report an increase in the incidence of animal diseases that is attributed to CC (Hussain et al., 2016). Furthermore, the impacts of CC on crops and livestock are strongly linked; for instance, the decrease in the growth of forages reduce livestock weight gains (Butt et al., 2005). Further studies also analyse the potential adverse effects of CC on fisheries (Ding et al., 2017; Lam et al., 2012; Lauria et al., 2018). Referring to the Ganges-Brahmaputra-Meghna (Bangladesh/India) and the Volta (Ghana) deltas, Lauria et al. (2018) suggest that "changes in temperature and primary production could reduce fish productivity and fisheries income especially in the Volta and Bangladesh deltas" (p. 1566). The impacts of $\mathrm{CC}$ on fisheries, and consequently fish-based economies, are expected to be particularly high in Small Island Developing States (SIDS) (Dey et al., 2016; Moustache, 2017). 
Most of the scholarly literature focuses on CC damages on agriculture thus food availability; nevertheless, Hasegawa et al. (2018) point out that stringent CC mitigation measures can also increase the risk of food insecurity in SSA. Hence, the challenge ahead is how to balance socio-economic development (including food security) and environmental conservation (e.g. CC mitigation) (Rudi et al., 2012). Moreover, some scholars assume that the so-called 'carbon fertilisation' may offset somehow the impact of CC on crop yields. In fact, Roudier et al. (2011) highlight "the pivotal role that the carbon fertilization effect may have on the sign and amplitude of change in crop yields" (p. 1073). Likewise, Sultan and Gaetani (2016) point out that "a robust evidence of yield loss in West Africa emerges. This yield loss is mainly driven by increased mean temperature while potential wetter or drier conditions as well as elevated $\mathrm{CO} 2$ concentrations can modulate this effect". Moreover, global warming could expand both the agricultural area and growing season in some northern countries such as Russia (Kiselev et al., 2013), with positive effects on agriculture production.

Yields and productivity declines can have serious implications also for the other FS dimensions, especially food access and food utilisation. For instance, Solaymani (2018) shows a "negative impact of rainfall-temperature variability [...] on food availability and access to food due to a reduction in the supply of agricultural products, a commodity inflation pressure and a reduction in household income" (p. 1575) in Malaysia. Wheeler and von Braun (2013) argue that "food access and utilization will be affected indirectly via collateral effects on household and individual incomes, and food utilization could be impaired by loss of access to drinking water and damage to health" (p. 508).

\section{Climate change and food access}

Climate change will reduce food access through negative impacts on both food prices and rural livelihoods. Food supply shortfalls, due to negative impacts of CC on yields and production, would increase food prices. Increases in food prices would affect millions of low-income people that live in areas that are already affected by high rates of hunger and poverty, such as South Asia (Bandara \& Cai, 2014) and SSA (Tamako \& Thamaga-Chitja, 2017). Tamako and Thamaga-Chitja (2017) suggest that "Sub-Saharan Africa is faced with a range of climate risks, which include rapid and uncertain changes in rainfall and temperature patterns that threaten food production, and could lead to an increase in food prices and food insecurity" (p. 16). Poor urban and rural people, most of whom are net food buyers and already spend a high share of their income on food, would find it more difficult to meet their dietary needs, which increase the risk of food insecurity and hunger. The situation is particularly alarming for populations that depend on agriculture for their livelihoods and income, especially small-scale farmers in the Global South (Descheemaeker et al., 2016; García de Jalón et al., 2018; Williams et al., 2018; Wood et al., 2014). In this regard, Williams et al. (2018) put that "The impacts of changing climate on agriculture have consequences on livelihoods and food security. Smallholder 
farmers, who have heterogeneous farming systems and limited resources, compounded with multiple risks, are greatly affected". Akinseye et al. (2020) argue that "Climate variability and change will have far reaching consequences for smallholder farmers in sub-Saharan Africa, the majority of whom depend on agriculture for their livelihoods". Indeed, rural populations will suffer from the increase of food prices as well as the negative impacts of CC on their sources of income and livelihoods strategies relating to agriculture. Indeed, agricultural production loss implies the loss of income for farmers and of revenues for countries (Sultan et al., 2019) as agriculture is an important source of income and livelihoods in rural areas and a significant contributor to the national gross domestic product in developing countries (Diao et al., 2007). Decrease of production will be often combined with the loss of livelihoods assets due to the increase of the intensity and frequency of climate-related disasters (Habiba et al., 2016; Poudel et al., 2017). Indeed, severe droughts or floods can dramatically reduce incomes and cause asset losses thus eroding income earning capacity. Poor rural people (e.g. smallholders, agricultural workers) are particularly vulnerable to disaster impacts.

The impacts of CC will be also high on food importing countries as food exports might be reduced or banned in case of extreme climate events. For instance, Qureshi et al. (2013) show that CC will reduce Australian food exports and put that "Despite its relatively small contribution to total global food supply, Australia's contribution to international trade in wheat, meat and dairy products is substantial and could affect global food prices" (136), especially in South and South-East Asia, which already suffer from food insecurity. While most of the focus is on the impacts of $\mathrm{CC}$ on economic accessibility (i.e. affordability), $\mathrm{CC}$ will also impact food physical accessibility in remote regions. For instance, referring to the Himalayan region, Hussain et al. (2016) report that "After hazards, households face transitory food insecurity owing to damage to their local food systems and livelihood sources, and constrained food supply from other areas" (p. 921). Gregory et al. (2005) highlight the diversity of pathways through which CC affects FS and argue that "Climate change may affect food systems in several ways ranging from direct effects on crop production (e.g. changes in rainfall leading to drought or flooding, or warmer or cooler temperatures leading to changes in the length of growing season), to changes in markets, food prices and supply chain infrastructure" (p. 2139).

\section{Climate change and food utilisation}

Climate variability will change food utilisation with impacts on the nutrition status of the populations, especially poor and vulnerable people. For instance, higher temperatures can favour the development of pathogens, while water scarcity (induced by droughts) affects water quality and hygiene habits, especially in arid and semi-arid areas, which could increase the burden of diseases (e.g. diarrhoea) (FAO, 2016), especially among the poor children. Indeed, the impacts of malnutrition caused by global warming might be 
particularly severe among vulnerable groups such as children (Belesova et al., 2019; Sorgho et al., 2016) and women (Bryan et al., 2018). Also the dietary patterns of indigenous communities will be particularly affected (Smith et al., 2019; Wesche \& Chan, 2010); referring to the Inuit in the Canadian Arctic, Wesche and Chan (2010) argue that "Changing access to, availability of, quality of, and ability to use traditional food resources has implications for quality of diet. Nutritional implications of lower traditional food use include likely reductions in iron, zinc, protein, vitamin $\mathrm{D}$, and omega-3 fatty acids, among others" (p. 361). CC will also affect food utilisation in other ways such as reducing the nutrient content of staple crops and increasing the risk of food contamination (Lake et al., 2012; Medina et al., 2017). Indeed, CC will have notable impacts on food utilisation, including nutrition and food safety (Lake et al., 2012). Lake et al. (2012) highlight the relation between food access and food utilisation dimensions of FS in the context of changing climate and suggest that "Increasing food prices may lower the nutritional quality of dietary intakes, exacerbate obesity, and amplify health inequalities. Altered conditions for food production may result in [...] altered use of pesticides and veterinary medicines, and affect the main transfer mechanisms through which contaminants move from the environment into food. All these have implications for food safety and the nutritional content of food" (p. 1520). Moreover, the literature points to some potential links between CC and diet-related non-communicable diseases (NCDs) (Savage et al., 2020). Other scholars analyse the linkage between CC and food utilisation the other way round and point out to the need to move towards dietary patterns that have lower GHG emissions to mitigate CC (Lake et al., 2012). Esham et al. (2018) point out that little attention is paid to the impacts of CC on access and utilization dimensions of FS and highlight that "achieving food security necessitates action beyond building climate resilient food production systems to a holistic approach that is able to ensure climate resilience of the entire food system while addressing nutritional concerns arising from impacts of climate change" (p. 1017). This implies expanding the narrow focus from the impacts of the changing climate on crop yield and productivity to include the impact on the nutritional value of crops (Leisner, 2020) and, consequently, diets.

\section{Climate change and food system stability}

Climate variability and the increasingly frequent and intensive extreme climate events will affect the stability of food availability, access and use. This will likely happen through changes in seasonality, fluctuations in ecosystem productivity, increased risks and reduced predictability of food supply (FAO, 2016). This will be a major problem especially for SIDS and landlocked countries, which are more vulnerable to both food supply and trade disruptions. Referring to the islands of the South Pacific, Barnett (2011) shows that "climate change will adversely affect food systems in the region, including the supply of food from agriculture and fisheries, the ability of countries to import food, systems for the distribution of food, and the ability of households to purchase and 
utilize food" (p. 229). CC will affect all the elements of and activities within the food system (HLPE, 2014) with cascading effects and far-reaching implications in terms of FS at global, national and local levels (Myers et al., 2017; Schnitter \& Berry, 2019). The short-term effects of temperature increase and rainfall variability on crop yields can have long-term effects on global food system stability. In this regard, Wheeler and von Braun (2013) put that "A robust and coherent global pattern is discernible of the impacts of climate change on crop productivity that could have consequences for food availability. The stability of whole food systems may be at risk under climate change because of short-term variability in supply" (p. 508). Climate variability would also increase price volatility (Baldos \& Hertel, 2015; Takle et al., 2013). The recognition of the impacts of $\mathrm{CC}$ on food availability, access and utilisation and their stability over time implies the need of adopting a food system approach. In this respect, Keller et al. (2018) point out that "Efficient responses require an understanding of the full spectrum of potential climate impacts on food utilization, access and availability, as well as on the underlying natural, built and governance systems" (p. 742).

\section{FOOD SECURITY AND CLIMATE CHANGE MITIGATION}

The relation between CC and FS is dual but much more attention is paid in the literature to the impacts of CC on food security. In this respect, Islam and Wong (2017) argue that "it seems that research on climate change and food in/security has often been one-sided; with climate change being identified as the cause of food insecurity and not how the systems in place to ensure food security have exacerbated the issue of climate change". Agriculture is a main contributor to $\mathrm{CC}$, through GHG emissions, and one of the most affected sectors by CC (FAO, 2016; HLPE, 2012). Agriculture, forestry and other land uses (AFOLU) account for about a fifth of GHG emissions worldwide (FAO, 2016). Indeed, Torquebiau (2017) suggests that "Agriculture is probably the most climatedependent human activity and is both victim and responsible for climate change, while it can also be a solution to the climate change crisis". In this context, sustainable intensification is presented as a win-win strategy to combine FS and CC mitigation (Ayantunde et al., 2020; Descheemaeker et al., 2016; van Loon et al., 2019). However, referring to cereal cropping in SSA, van Loon et al. (2019) conclude that while "intensification scenarios are clearly superior to expansion scenarios in terms of climate change mitigation" (p. 3720), "Intensification will come, depending on the nutrient use efficiency achieved, with large increases in nutrient inputs and associated GHG emissions" (p. 3720). Many scholars highlighted the benefits of climate-smart agriculture (CSA) (Abegunde et al., 2019; García de Jalón et al., 2017) both for CC mitigation and adaptation. Loboguerrero et al. (2019) argue that "Climate-smart agriculture can help foster synergies between productivity, adaptation, and mitigation". In this context, FAO (2016) suggests that "Food and agriculture must be central to global efforts to adapt to climate change, through policies and actions that address vulnerabilities 
and risks and promote agricultural systems that are resilient and sustainable $[\ldots]$ Delaying the transformation of the agricultural sectors will force poorer countries to fight poverty, hunger and climate change at the same time".

\section{CONCLUSIONS}

This paper presents a comprehensive review on the multifaceted relationships between $\mathrm{CC}$ and food security. It shows an increasing academic interest in the nexus between CC and the different dimensions of food security. However, most of the articles deal with the effects of $\mathrm{CC}$ on food availability and agriculture (especially crop production) while analyses regarding the remaining dimensions of FS are rather scarce. The effects of CC on food security, that are expected to intensify over time, vary across countries and world regions. Indeed, effects are expected to be higher in developing countries whose economies are very dependent on the performance of rain-fed agriculture. Furthermore, the review shows that there is a dual relationship between climate change and food security. Both strategies for CC mitigation and adaptation have an impact on food security. The multifaceted and multidimensional relations between CC and FS call for adopting reflexive governance arrangements and integrated policies that maximise co-benefits while addressing trade-offs between climate and FS (e.g. agriculture) policies. This is of paramount importance to make sure that strategies for CC mitigation and/or adaptation do not jeopardize efforts for ending hunger and eradicating all forms of malnutrition in the framework of the implementation of the 2030 Agenda for Sustainable Development. In this respect, further efforts are needed in science, policy and practice to foster transition towards low emissions and climate resilient agriculture and food systems to achieve the longterm climate neutrality and food security objectives. Likewise, it is necessary to promote approaches that deliver mitigation, adaptation and development cobenefits, especially in the Global South.

\section{ACKNOWLEDGEMENTS}

This work was carried out within the project SUSTLIVES (SUSTaining and improving local crop patrimony in Burkina Faso and Niger for better LIVes and EcoSystems) of the DeSIRA initiative (Development Smart Innovation through Research in Agriculture) financed by the European Union.

\section{REFERENCES}

Abegunde V. O., Sibanda M., Obi A. (2019). The Dynamics of Climate Change Adaptation in Sub-Saharan Africa: A Review of Climate-Smart Agriculture among Small-Scale Farmers. Climate, 7(11), 132. https://doi.org/10.3390/cli7110132

Adhikari U., Nejadhashemi A. P., Woznicki S. A. (2015). Climate change and eastern Africa: a review of impact on major crops. Food and Energy Security, 4(2), 110 132.

Akinbile C. O., Akinlade G. M., Abolude A. T. (2015). Trend analysis in climatic variables and impacts on rice yield in Nigeria. Journal of Water and Climate Change, 6(3), 534-543. 
Akinseye F. M., Ajeigbe H. A., Traore P. C. S., Agele S. O., Zemadim B., Whitbread, A. (2020). Improving sorghum productivity under changing climatic conditions: A modelling approach. Field Crops Research, 246, 107685. https://doi.org/10.1016/j.fcr.2019.107685

Ayantunde A. A., Oluwatosin B. O., Yameogo V., van Wijk M. (2020). Perceived benefits, constraints and determinants of sustainable intensification of mixed crop and livestock systems in the Sahelian zone of Burkina Faso. International Journal of Agricultural Sustainability, 18(1), 84-98. https://doi.org/10.1080/14735903.2019.1698494

Baldos U. L. C. \& Hertel T. W. (2015). The role of international trade in managing food security risks from climate change. Food Security, 7(2), 275-290.

Bandara J. S. \& Cai Y. (2014). The impact of climate change on food crop productivity, food prices and food security in South Asia. Economic Analysis and Policy, 44(4), $451-465$.

Barnett J. (2011). Dangerous climate change in the Pacific Islands: food production and food security. Regional Environmental Change, 11(S1), 229-237.

Belesova K., Gornott C., Milner J., Sié A., Sauerborn R., Wilkinson P. (2019). Mortality impact of low annual crop yields in a subsistence farming population of Burkina Faso under the current and a $1.5^{\circ} \mathrm{C}$ warmer climate in 2100 . Science of The Total Environment 691, 538-548. https://doi.org/10.1016/j.scitotenv.2019.07.027

Bryan E., Bernier Q., Espinal M., Ringler C. (2018). Making climate change adaptation programmes in sub-Saharan Africa more gender responsive: insights from implementing organizations on the barriers and opportunities. Climate and Development 10(5), 417-431.

Butt T. A., McCarl B. A., Angerer J., Dyke P. T., Stuth J. W. (2005). The economic and food security implications of climate change in Mali. Climatic Change, 68(3), 355378.

Capone R., Bottalico F., Ottomano Palmisano G., El Bilali H., Dernini S. (2018). Food systems sustainability, food security and nutrition in the Mediterranean region: The contribution of the Mediterranean diet. In, Encyclopedia of Food Security and Sustainability, Volume 2. Elsevier, Amsterdam. pp. 176-180. https://doi.org/10.1016/B978-0-08-100596-5.21977-X

Capone R., El Bilali H., Debs Ph., Bottalico F. (2016). Relations between food and nutrition security, diets and food systems. Agriculture and Forestry 62(1): 49-58. DOI: 10.17707/AgricultForest.62.1.05.

Cadro, S., Uzunović, M., Cherni-Cadro, S., Zurovec, J. (2019). Changes in the water balance of Bosnia and Herzegovina as a result of climate change. Agriculture and Forestry, 65 (3): 19-33

Committee on World Food Security. (2012). Coming to terms with terminology: Food security, Nutrition security, Food security and nutrition, Food and nutrition security. Rome.

Cooper P. J. M., Dimes J., Rao K. P. C., Shapiro B., Shiferaw B., Twomlow S. (2008). Coping better with current climatic variability in the rain-fed farming systems of sub-Saharan Africa: An essential first step in adapting to future climate change? Agriculture, Ecosystems \& Environment, 126(1-2), 24-35. https://doi.org/10.1016/j.agee.2008.01.007

Čustović H., Đikić M., Ljuša M., Žurovec O. (2012). Effect of Climate Changes on Agriculture of the Western Balkan Countries and Adaptation Policies. Agriculture \& Forestry, 58 (2): 127-141. 
Davenport F., Funk C., Galu G. (2018). How will East African maize yields respond to climate change and can agricultural development mitigate this response? Climatic Change, 147(3-4), 491-506. https://doi.org/10.1007/s10584-018-2149-7

Descheemaeker K., Oosting S. J., Homann-Kee Tui S., Masikati P., Falconnier G. N., Giller, K. E. (2016). Climate change adaptation and mitigation in smallholder croplivestock systems in sub-Saharan Africa: a call for integrated impact assessments. Regional Environmental Change, 16(8), 2331-2343.

Dey M. M., Gosh K., Valmonte-Santos R., Rosegrant M. W., Chen O. L. (2016). Economic impact of climate change and climate change adaptation strategies for fisheries sector in Solomon Islands: Implication for food security. Marine Policy, 67, 171-178.

Diao X., Hazell P., Resnick D., Thurlow J. (2007). The Role of Agriculture in Development: Implications for Sub-Saharan Africa. Washington D.C.: International Food Policy Research Institute. https://doi.org/10.2499/9780896291614RR153

Ding Q., Chen X., Hilborn R., Chen Y. (2017). Vulnerability to impacts of climate change on marine fisheries and food security. Marine Policy, 83, 55-61.

El Bilali H. (2019). Research on agro-food sustainability transitions: where are food security and nutrition? Food Security 11(3):559-577. DOI: https://doi.org/10.1007/s12571-019-00922-1

El Bilali H., Callenius C., Strassner C., Probst L. (2018). Food and nutrition security and sustainability transitions in food systems. Food and Energy Security; e00154. https://doi.org/10.1002/fes3.154

El Bilali H. (2018). Relation between innovation and sustainability in the agro-food system. Italian Journal of Food Science 30: 200-225. https://doi.org/10.14674/IJFS1096

Ericksen P. J. (2008). Conceptualizing food systems for global environmental change research. Global Environmental Change, 18(1), 234-245.

Esham M., Jacobs B., Rosairo H.S.R., Siddighi B.B. (2018). Climate change and food security: A Sri Lankan perspective. Environment, Development and Sustainability 20(3): 1017-1036. https://doi.org/10.1007/s10668-017-9945-5

FAO (2009). Declaration of the World Food Summit on Food Security. Rome.

FAO (2014). Building a common vision for sustainable food and agriculture - Principles and Approaches. Rome.

FAO (2016). The State of Food and Agriculture: Climate Change, Agriculture and Food Security. Rome.

FAO, IFAD, UNICEF, WFP \& WHO (2019). The State of Food Security and Nutrition in the World 2019 - Safeguarding against economic slowdowns and downturns. Rome.

FAO, WFP \& IFAD (2013). The State of Food Insecurity in the World 2013: The Multiple Dimensions of Food Security. Rome.

Freduah B., MacCarthy D., Adam M., Ly M., Ruane A., Timpong-Jones E., ... Adiku S. (2019). Sensitivity of Maize Yield in Smallholder Systems to Climate Scenarios in Semi-Arid Regions of West Africa: Accounting for Variability in Farm $\begin{array}{llll}\text { Management } \quad \text { Practices. } & \text { Agronomy, } & 939),\end{array}$ https://doi.org/10.3390/agronomy9100639

García de Jalón S., Iglesias A., Neumann M. B. (2018). Responses of sub-Saharan smallholders to climate change: Strategies and drivers of adaptation. Environmental Science \& Policy, 90, 38-45. https://doi.org/10.1016/j.envsci.2018.09.013

García de Jalón S., Silvestri S., Barnes A. P. (2017). The potential for adoption of climate smart agricultural practices in Sub-Saharan livestock systems. Regional Environmental Change, 17(2), 399-410. https://doi.org/10.1007/s10113-016-1026- 
Godber O. F., Wall R. (2014). Livestock and food security: vulnerability to population growth and climate change. Global Change Biology, 20(10), 3092-3102.

Gregory P., Ingram J.S., Brklacich M. (2005). Climate change and food security. Philosophical Transactions of the Royal Society B: Biological Sciences, 360(1463), 2139-2148.

Habiba U., Abedin M. A., Shaw R. (2016). Food Security, Climate Change Adaptation, and Disaster Risk. In J. Uitto \& R. Shaw (Eds.), Sustainable Development and Disaster Risk Reduction (pp. 87-101). Tokyo: Springer.

Hasegawa T., Fujimori S., Havlík P., Valin H., Bodirsky B. L., Doelman J. C., ... Witzke P. (2018). Risk of increased food insecurity under stringent global climate change mitigation policy. Nature Climate Change, 8(8), 699-703.

HLPE (2012). Food security and climate change. A report by the High Level Panel of Experts on food security and nutrition of the Committee on World Food Security. Rome.

HLPE (2014). Note on Critical and Emerging Issues for Food Security and Nutrition. Rome.

Hussain A., Rasul G., Mahapatra B., Tuladhar S. (2016). Household food security in the face of climate change in the Hindu-Kush Himalayan region. Food Security, 8(5), 921-937.

Intergovernmental Panel on Climate Change (2012). Sustainable Development and mitigation. In Climate Change 2007 (pp. 691-744). Cambridge: Cambridge University Press.

Islam M. \& Wong A. (2017). Climate Change and Food In/Security: A Critical Nexus. Environments, 4(2), 38. https://doi.org/10.3390/environments4020038

Keller M., Zamudio A. N., Bizikova L., Sosa A. R., Gough A. M. (2018). Food security and climate change from a systems perspective: community case studies from Honduras. Climate and Development, 10(8), 742-754.

Kiselev S., Romashkin R., Nelson G. C., Mason-D’Croz D., Palazzo A. (2013). Russia's Food Security and Climate Change: Looking into the Future. Economics, 7(201339), 1. https://doi.org/10.5018/economics-ejournal.ja.2013-39

Lake I. R., Hooper L., Abdelhamid A., Bentham G., Boxall A. B. A., Draper A., ... Waldron K. W. (2012). Climate Change and Food Security: Health Impacts in Developed Countries. Environmental Health Perspectives, 120(11), 1520-1526.

Lam V., Cheung W., Swartz W., Sumaila U. (2012). Climate change impacts on fisheries in West Africa: implications for economic, food and nutritional security. African Journal of Marine Science, 34(1), 103-117. https://doi.org/10.2989/1814232X.2012.673294

Lauria V., Das I., Hazra S., Cazcarro I., Arto I., Kay S., ... Fernandes J. A. (2018). Importance of fisheries for food security across three climate change vulnerable deltas. Science of The Total Environment, 640-641, 1566-1577.

Leisner C. P. (2020). Review: Climate change impacts on food security- focus on perennial cropping systems and nutritional value. Plant Science, 293, 110412.

Loboguerrero A. M., Campbell B., Cooper P., Hansen J., Rosenstock T., Wollenberg E. (2019). Food and Earth Systems: Priorities for Climate Change Adaptation and Mitigation for Agriculture and Food Systems. Sustainability, 11(5), 1372.

Mare F., Bahta Y. T., Van Niekerk W. (2018). The impact of drought on commercial livestock farmers in South Africa. Development in Practice, 28(7), 884-898.

Medina A., Akbar A., Baazeem A., Rodriguez A., Magan, N. (2017). Climate change, food security and mycotoxins: Do we know enough? Fungal Biology Reviews, 31(3), 143-154. 
Moustache A. M. (2017). Adaptation to Impacts of Climate Change on the Food and Nutrition Security Status of a Small Island Developing State. In Natural Resources Management (pp. 919-944). Hersey (PA, USA): IGI Global.

Muchuru S. \& Nhamo G. (2019). A review of climate change adaptation measures in the African crop sector. Climate and Development, 11(10), 873-885.

Mugambiwa S. S. \& Tirivangasi H. M. (2017). Climate change: A threat towards achieving 'Sustainable Development Goal number two' (end hunger, achieve food security and improved nutrition and promote sustainable agriculture) in South Africa. Jàmbá: Journal of Disaster Risk Studies, 9(1). https://doi.org/10.4102/jamba.v9i1.350

Murray-Tortarolo G. N., Jaramillo V. J., Larsen J. (2018). Food security and climate change: the case of rainfed maize production in Mexico. Agricultural and Forest Meteorology, 253-254, 124-131. https://doi.org/10.1016/j.agrformet.2018.02.011

Myers S. S., Smith M. R., Guth S., Golden C. D., Vaitla B., Mueller N. D., ... Huybers P. (2017). Climate Change and Global Food Systems: Potential Impacts on Food Security and Undernutrition. Annual Review of Public Health, 38(1), 259-277.

Naah J.-B. \& Braun B. (2019). Local agro-pastoralists' perspectives on forage species diversity, habitat distributions, abundance trends and ecological drivers for sustainable livestock production in West Africa. Scientific Reports, 9(1), 1707.

Poudel S., Funakawa S., Shinjo H. (2017). Household Perceptions about the Impacts of Climate Change on Food Security in the Mountainous Region of Nepal. Sustainability, 9(4), 641.

Qureshi M., Hanjra M. A., Ward J. (2013). Impact of water scarcity in Australia on global food security in an era of climate change. Food Policy, 38, 136-145.

Ramasamy S. (2010). World Food Security: The Challenges of Climate Change and Bioenergy. In R. Lal, M. Sivakumar, S. Faiz, A. Rahman, \& K. Islam (Eds.), Climate Change and Food Security in South Asia (pp. 183-213). Dordrecht: Springer.

Roudier P., Sultan B., Quirion P., Berg A. (2011). The impact of future climate change on West African crop yields: What does the recent literature say? Global Environmental Change, 21(3), 1073-1083. https://doi.org/10.1016/j.gloenvcha.2011.04.007

Rudi L.-M., Azadi H., Witlox F. (2012). Reconcilability of Socio-Economic Development and Environmental Conservation in Sub-Saharan Africa. Global and Planetary Change, 86-87, 1-10.

Savage A., McIver L., Schubert L. (2020). Review: the nexus of climate change, food and nutrition security and diet-related non-communicable diseases in Pacific Island Countries and Territories. Climate and Development, 12(2), 120-133.

Schnitter R. \& Berry P. (2019). The Climate Change, Food Security and Human Health Nexus in Canada: A Framework to Protect Population Health. International Journal of Environmental Research and Public Health, 16(14), 2531.

Simunic, I., Likso, T., Miseckaite, O., Orlović-Leko, P., Ciglenečki, I., Spalević, V. (2019). Climate changes and soil water regime. Agriculture and Forestry, 65(3): 05-18. DOI: 10.17707/AgricultForest.65.3.01

Smith E., Ahmed S., Dupuis V., Running Crane M., Eggers M., Pierre M., ... Byker Shanks C. (2019). Contribution of Wild Foods to Diet, Food Security, and Cultural Values Amidst Climate Change. Journal of Agri., Food Syst. and Com. Dev., 9, 124. 
Solaymani, S. (2018). Impacts of climate change on food security and agriculture sector in Malaysia. Environment, Development and Sustainability, 20(4), 1575-1596.

Sorgho R., Franke J., Simboro S., Phalkey R., Saeurborn R. (2016). NUTRItion and CLIMate (NUTRICLIM): investigating the relationship between climate variables and childhood malnutrition through agriculture, an exploratory study in Burkina Faso. Public Health Reviews, 37(1), 16. https://doi.org/10.1186/s40985-016-0031-6

Steffen W., Richardson K., Rockstrom J., Cornell S. E., Fetzer I., Bennett E. M., ... Sorlin S. (2015). Planetary boundaries: Guiding human development on a changing planet. Science, 347(6223), 1259855-1259855. https://doi.org/10.1126/science.1259855

Sultan B., Defrance D., Iizumi T. (2019). Evidence of crop production losses in West Africa due to historical global warming in two crop models. Scientific Reports, 9(1), 12834.

Sultan B. \& Gaetani M. (2016). Agriculture in West Africa in the Twenty-First Century: Climate Change and Impacts Scenarios, and Potential for Adaptation. Frontiers in Plant Science, 7. https://doi.org/10.3389/fpls.2016.01262

Takle E. S., Gustafson D., Beachy R., Nelson G. C., Mason-D’Croz D., Palazzo A. (2013). US Food Security and Climate Change: Agricultural Futures. Economics 7(2013-34), 1. https://doi.org/10.5018/economics-ejournal.ja.2013-34

Tamako N. \& Thamaga-Chitja J. M. (2017). Does social capital play a role in climate change adaptation among smallholder farmers for improving food security and livelihoods? Food and Nutrition Challenges in Southern Africa, 16-27.

Torquebiau E. (2017). Le changement climatique, un défi pour la recherche : l'exemple de l'initiative « 4 \%o ». OCL, 24(1), 108. https://doi.org/10.1051/ocl/2016054

Trnka M., Feng S., Semenov M. A., Olesen J. E., Kersebaum K. C., Rötter R. P., ... Büntgen U. (2019). Mitigation efforts will not fully alleviate the increase in water scarcity occurrence probability in wheat-producing areas. Science Advances, 5(9), e2406.

United Nations (2015a). The Millennium Development Goals Report 2015. New York.

United Nations (2015b). Transforming Our World: The 2030 Agenda for Sustainable Development. Resolution adopted by the General Assembly on 25 September 2015. New York.

United Nations System High Level Task Force on Global Food Security (2011). Food and Nutrition Security: Comprehensive Framework for Action. Summary of the Updated Comprehensive Framework for Action (UCFA). Rome.

van Loon M. P., Hijbeek R., Berge H. F. M., De Sy V., Broeke G. A., Solomon D., Ittersum M. K. (2019). Impacts of intensifying or expanding cereal cropping in subSaharan Africa on greenhouse gas emissions and food security. Global Change Biology 25(11), 3720-3730. https://doi.org/10.1111/gcb.14783

van Oort P. A. J. \& Zwart S. J. (2018). Impacts of climate change on rice production in Africa and causes of simulated yield changes. Global Change Biology, 24(3), 10291045.

Waha K., Müller C., Rolinski S. (2013). Separate and combined effects of temperature and precipitation change on maize yields in sub-Saharan Africa for mid- to late-21st century. Global and Planetary Change, 106, 1-12.

Webersik C. \& Wilson C. (2009). Achieving environmental sustainability and growth in Africa: the role of science, technology and innovation. Sustainable Development, 17(6), 400-413. https://doi.org/10.1002/sd.411 
Wesche S. D. \& Chan H. M. (2010). Adapting to the Impacts of Climate Change on Food Security among Inuit in the Western Canadian Arctic. EcoHealth, 7(3), 361-373.

Wheeler T. \& von Braun J. (2013). Climate Change Impacts on Global Food Security. Science, 341(6145), 508-513. https://doi.org/10.1126/science.1239402

Williams P. A., Crespo O., Abu M., Simpson N. P. (2018). A systematic review of how vulnerability of smallholder agricultural systems to changing climate is assessed in Africa. Environmental Research Letters, 13(10), 103004.

Wood S. A., Jina A. S., Jain M., Kristjanson P., DeFries R. S. (2014). Smallholder farmer cropping decisions related to climate variability across multiple regions. Global Environmental Change, 25, 163-172. https://doi.org/10.1016/j.gloenvcha.2013.12.011

Zougmoré R. B., Partey S. T., Ouédraogo M., Torquebiau E., Campbell B. M. (2018). Facing climate variability in sub-Saharan Africa: analysis of climate-smart agriculture opportunities to manage climate-related risks. Cahiers Agricultures, $27(3), 34001$. 